\title{
Free Movement? The Impact of Legislation, Benefit Generosity and Wages on the Pensions of European Migrants
}

Traute Meyer*, Paul Bridgen and Caroline Andow

School of Social Sciences, University of Southampton, Southampton, UK

\section{ABSTRACT}

European (EU) economic integration has always involved a commitment to the free movement of labour, services and capital. However, the development by EU institutions of specific rights with respect to labour mobility has been slow. This paper explores this issue from the perspective of pension rights, among the most long-lasting for citizens. It shows that the literature on this topic has focussed mainly on EU regulations, their scope and limitations. The paper argues that, although important, this work has led to the neglect of a more fundamental issue: the potential impact on mobility of the relative generosity of pension schemes and large national wealth variations, an increasingly salient issue since the expansion of the EU into Eastern and Central Europe. Thus, on the basis of a detailed review of dominant intra-EU migratory patterns, the paper investigates the impact on pension rights of movement between Beveridgean and Bismarckian pension systems and between countries of substantially different wealth. It shows that lower income workers who move from Beveridgean to Bismarckian countries would be most at risk of pension losses. However, such movement is unusual; instead, the majority of intra-EU migrants move from Bismarckian systems of low generosity in the poorer east to Beveridgean and more generous Bismarckian in the richer west. Workers who make this move are more likely to experience pension gains than losses. For them, free movement is achieved. Copyright $(\subset 2013$ John Wiley \& Sons, Ltd.

*Correspondence to: Traute Meyer, Social Sciences, Faculty of Social and Human Sciences, University of Southampton, Highfield, Southampton SO17 1BJ, UK.

E-mail: t.meyer@soton.ac.uk
Accepted 8 February 2013

Keywords: EU migration; labour mobility; pension legislation; pensions generosity; Bismarckian pension system; Beveridgean pension system

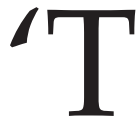

he Community shall have as its task, by establishing a common market and progressively approximating the economic policies of member states, to promote throughout the Community a harmonious development of economic activities, a continuous and balanced expansion, an increase in stability, and accelerated raising of the standard of living and closer relations between the States belonging to it.... the activities of the Community shall include (...) the abolition, as between member states, of obstacles to freedom of movement for persons, services and capital. Such freedom of movement shall entail the abolition of any discrimination based on nationality between workers of the member states as regards employment, remuneration and other conditions of work and employment'.

Articles 2-3, 48.2 Treaty establishing The European Economic Community, 1957

When the European Economic Community was founded in 1957, its purpose was a peaceful and stable Europe, and the creation of a common market was considered to be central to achieving this aim. Mobile citizens were constituents of this common market from the start, and to enable mobility, the Community pledged to remove obstacles workers might face. ${ }^{1}$ This was the theory. In practice, it took a long time until more specific rights were introduced, and until today, mobile workers might well be penalised for moving between countries.

This paper explores the mobility of social rights in Europe from the perspective of pensions, among 
the most significant and long-lasting for citizens. In order not to be disadvantaged in comparison with an immobile employee, a mobile worker needs to be able to preserve their pension rights, otherwise citizens who move risk losing their benefits and could face poverty in retirement. It is therefore important to know how the broad guarantees given by the European Communities in 1957 (EC) look from this more detailed perspective.

Too little is known about the extent to which transnational mobile workers are penalised in comparison with immobile ones. The literature has superficially analysed the EU legislation of public pensions and how the principles of defined benefit occupational schemes hinder mobility but has not investigated comparatively how the legislation of national occupational pensions affects mobile workers. Moreover, how well entitlements accrued nationally are protected is not the only criterion that decides whether migrants are penalised by moving: differences in principles and generosities of pension systems, and in average wage levels between countries also have an impact on migrants' post-retirement income.

Although some work has been carried out on these separate aspects of mobility, a more comprehensive, integrated approach is needed. This paper begins this task. It investigates potential hurdles to the freedom of movement created by legislation, system generosity and wage differences. It assumes that a EU mobile worker would need to answer three questions to assess their freedom of movement within the EU.

(1) Is my mobility protected by legislation? This question explores whether someone has the legal right to add all public and private pension entitlement from different EU countries.

(2) Is the pension system of my host country more or less generous than that of my home country? Differing national principles and levels of generosity will affect overall outcomes and therefore the opportunity to move permanently to another country.

(3) What is the average wage level of my home country in relation to my host country? Independent of system generosity, a pension pot accrued in a poorer country with lower wages might be too low to cover the higher living expenses in a richer country, whereas that accrued in a richer country might comfortably cover expenses in a poorer one.
The paper explores these questions on the basis firstly of a review of the literature and secondly, through an empirical investigation into the impact of pension scheme generosity and relative wage levels on the costs of mobility, an issue that has received much less attention in the literature. Our empirical research uses illustrative examples from countries selected according to the following criteria: firstly, we were interested in countries that receive the highest number of immigrants. We considered that countries with a higher share of mobile citizens, or with sudden influxes, are the most likely to have developed pension legislation that allows for mobility. Secondly, we deemed it important that our sample include an eastern EU country, poor compared with those in the west, so that we capture countries with more and less generous pension entitlements and significant differences in wage levels. Thirdly, we wanted to ensure that we could explore the impact of institutional diversity and therefore selected countries with different types of pension system.

The paper starts with an overview of the mobility of EU citizens. It will show two main streams of intra-EU migration since the collapse of the Soviet bloc, one from northeast to northwest and one from southeast to southwest. This section is followed by an overview of EU law regarding public and occupational pensions, which assesses the protective value of this legislation on the basis of a review of the available literature. Finally, an empirical investigation considers how the varying generosities and principles of pension systems and differences in the wealth of countries impact on mobile workers.

\section{MOBILITY OF WORKERS IN THE EUROPEAN $\mathrm{UNION}^{2}$}

\section{Before 1989}

After the Treaty of Rome was agreed in 1957, the market for goods integrated much faster than the labour market. Between 1960 and 1970, the interEC trade in goods increased rapidly, from $34 \%$ of all imports and exports of the six founding member states to $48 \%$ and to $60 \%$ of all 12 members by 1990 (Tsoukalis, 1997: 19). During the same period, only a small and in fact decreasing share of the EC population was mobile within Europe. Indeed, 
in the average of the period 1958-1980, trade within the EC as a proportion of all EC trade increased by $0.8 \%$ per year, whereas the movement of workers from one EC country to another as a proportion of the total number of labour migrants in the EC decreased by $1.3 \%$ per year (Straubhaar, 1988: 51). The movement of workers with EC citizenship as a share of all migrant workers in the EC fell from around $60 \%$ at the beginning of the 1960 s to $20 \%$ at the beginning of the 1970s, and it remained at this level until at least the late 1980s (Straubhaar, 1988:51). The intra EC labour market was characterised by 'free movement and little mobility' (Tsoukalis, 1997: 117). Migration within Europe as a share of the total population has been low in absolute terms and in comparison with the United States, Australia, Canada and Japan (Puhani, 2001: 129).

This relative immobility is not very surprising if we consider the difficulties of a person who moves away from the country he or she was born in encounters: they leave behind their families and friends, must use another language and they have to live in a new cultural context. In the literature on migration, this is why it is assumed that one common reason people become migrants is that they are 'pushed' away from their countries of origin. They move when the economic or political problems in their home countries become so strong that they prefer the upheaval of leaving to the difficulties of staying. This is why before 1989, main movements within the internal market took place from south to north, that is, from the poorer regions, southern Italy, Greece, Portugal, Spain, to the richer countries (Tsoukalis, 1997: 118). Given this situation, EC institutions and legislators could afford to focus much more on rules and regulations for cheese, car tyres and other goods than on removing the obstacles for persons. Furthermore, the 1960s and early 1970s are generally regarded as the 'golden age' of the welfare state, that is, as a time when unprecedented economic growth strengthened trade unions and enabled governments to expand their national welfare states. This means member states focused on national protection rather than EC mobility during that time (Tsoukalis, 1997: 22).

After the collapse of the Soviet bloc, migration began to increase, and in 2004, 15 years later the now European Union was extended to include Poland, Hungary, the Czech Republic, Slovenia, Slovakia, Estonia, Lithuania and Latvia. In 2007,
Bulgaria and Romania joined. The economies of Central and Eastern Europe were much poorer than those of the long-standing members, even if compared with the southern states of the EU15, and as a consequence, migration from these countries to western Europe increased rapidly, as we will show later.

\section{After 2000}

By the turn of the century, a significant number of EU citizens were living within Europe but outside their country of origin. Figure 1 shows EU foreign-born immigrants resident within different EU member states in 2000. The largest numbers were in Germany, France, the UK, Italy and Spain. In Eastern Europe, the Czech Republic received the largest number, but most of these immigrants came from the Slovak Republic. Because both countries were formerly part of Czechoslovakia, this could be considered migration within the same country. We therefore included Poland in our sample instead, which recorded the next highest number of immigrants. Of the selected countries, Germany, Spain, France, Italy and Poland represent the Bismarckian regime type, characterised by fairly generous earnings-related state benefits that mirror labour market performance. Only the UK is based on the Beveridgean model, for which flat-rate universal benefits are typical (see succeeding paragraphs for details of regimes). In line with our aim to investigate regime variation, we therefore added the Netherlands, another Beveridgean regime.

Between 2000 and 2009, the EU and EU+ $\mathrm{OECD}^{2}$ foreign populations ${ }^{3}$ in Spain, the UK, Italy and the Netherlands increased (Table 1). The increases were dramatic in Spain and Italy. The data are unreliable or missing for France and Poland, and in Germany, the EU foreign population did not increase and may have even declined. The small difference between the size of the EU foreign populations and the EU + OECD foreign populations shows that migrants are mostly from within the EU with the exception of Germany. ${ }^{4}$ Generally, the number of foreigners from within the EU increased faster than the number from EU and OECD countries combined. Thus, the proportion of intra-EU migrants amongst resident foreigners in these countries has increased. The UK is the only potential exception.

Popul. Space Place 19, 714-726 (2013) DOI: $10.1002 / p s p$ 


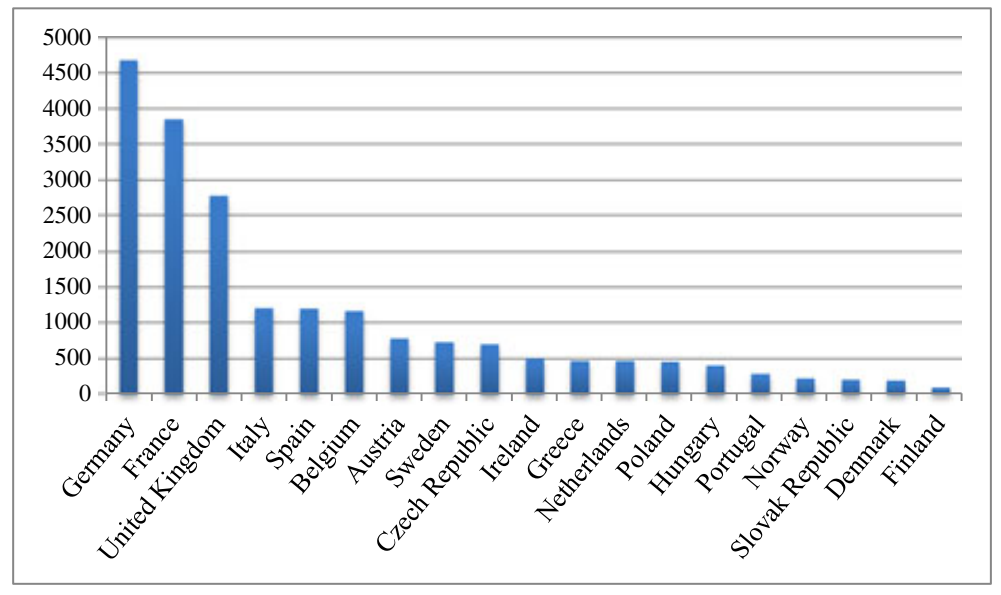

Source: OECD, Database on immigrants in OECD countries, OECD 2000 census, own calculations.

Figure 1. Foreign-born EU immigrants by country of residence, 2000 (thousands)

Source: OECD, Database on immigrants in OECD countries, OECD 2000 census, own calculations.

Table 1. Foreign nationality residents by country.

\begin{tabular}{lcccr}
\hline & $\begin{array}{c}\text { \% pop of EU foreign } \\
\text { nationality (2009) }\end{array}$ & $\begin{array}{c}\text { \% pop of EU + OECD } \\
\text { foreign nationality } \\
(2009)\end{array}$ & $\begin{array}{c}\text { \% change of EU foreign } \\
\text { nationality pop 2000- } \\
2009\end{array}$ & $\begin{array}{c}\% \text { change of EU + OECD } \\
\text { foreign nationality pop 2000- } \\
2009\end{array}$ \\
\hline Spain & $4.96-5.11$ & 5.43 & $329-464$ & 302 \\
UK & $2.91-3.1$ & 3.7 & $70-131$ & 99 \\
Germany & $2.88-3.09$ & 5.21 & -3 to 5 & -9 \\
Italy & $1.88-2.06$ & 2.18 & $338-359$ & 241 \\
France & $1.98-2.01^{11}$ & 2.51 & $0^{* *}$ & $::$ \\
Netherlands & $1.76-1.88$ & 2.66 & $34-40$ & 21 \\
Poland & 0.04 & 0.04 & $25-33^{* * *}$ & $0^{* * * *}$ \\
\hline
\end{tabular}

Source: Eurostat, Population and Social Conditions, International Migration and Asylum and OECD, International Migration Database and Population Statistics, own calculations. Where a range of values is shown, Eurostat and OECD data were used. ' $\because:$ ' represents missing data; *Size of population in 2007, data incomplete; **Eurostat data only, \% change 2003-2009; ***125 based on \% change 2001-2009 (Eurostat), 133 based on \% change 2002-2009 (OECD); ****\% change 2002-2009 (OECD).

Where do these migrants come from? The main migration flows into Spain, the UK, Italy and the Netherlands are from Romania and Poland (Table 2). In the north Polish, migrants have moved to the UK and Germany; in the south, Romanians have moved into Italy and Spain. There are smaller, yet still significant streams of Polish migrants to the Netherlands. The pattern of east to west migration in Europe has been recognised (for example Black et al., 2010), but the north/south divide has received less attention. Our inclusion of Poland as host country has shown that some, but comparatively fewer, move from a rich to a poor country. Therefore, EU enlargement has changed the patterns of migration, especially Italy and Spain changed from emigration to immigration countries. Migrants are young and often highly educated, but they are significantly deskilled in low-wage jobs in the destination countries (see for example Alexandru, 2007; Ahonen et al., 2009).

In summary, these data show that the social rights connected with mobility have become relevant for many EU citizens. The three questions posed at the start of this paper about the protection of such rights have thus become more salient. 
Table 2. Dominant nationality of inflow of migrants; EU foreign population per country.

\begin{tabular}{lcccc}
\hline Host country & Reference year & $\begin{array}{c}\text { Dominant nationality, EU } \\
\text { inward migrants }\end{array}$ & Reference year & $\begin{array}{c}\text { Dominant nationality, } \\
\text { EU foreign population }\end{array}$ \\
\hline Spain & 2009 & Romanian & 2009 & Romanian \\
Italy & 2007 & Romanian & 2009 & Romanian \\
Germany & 2008 & Polish & 2008 & Italian* \\
UK & 2005 & Polish & 2009 & Polish \\
Netherlands & 2009 & Polish & 2009 & German \\
Poland & 2009 & German & 2009 & German \\
\hline
\end{tabular}

Sources: Eurostat, Population and Social Conditions, and OECD, International Migration Database based on data derived from own calculations.

'Dominant' nationality: the nationality constituting the largest proportion of inward migrants or foreign population. France is not included because of a lack of reliable data. *This is the one exception to the north/south divide in migration.

\section{PORTABILITY OF PENSION RIGHTS IN THE EU - LEGISLATION AND ITS LIMITATIONS}

The first question a migrant worker within the EU needs to ask to assess the potential costs of mobility is whether legislation protects their social rights once they move. With regard to pension rights, this legislation falls under two types: EU law covers the mobility of public pensions between member states; national legislation covers the mobility of non-state pension rights.

\section{Statutory and Supplementary Pensions}

The first law about the portability of statutory social security rights for mobile workers (Regulation (EEC) 1408/71) only came into force in 1971, 14 years after the Treaty of Rome. ${ }^{5}$ This stipulates that a mobile worker should be treated like a national in the member state in which he or she chooses to work with the rules of only one member state applying to this worker at any one time. EU governments were aware that national systems were based on the assumption of lifelong membership and that mobile workers might therefore be penalised, so they put in place methods of calculations of benefits to avoid such effects. To establish an individual's pension after a pan-EU career, the pension administrators in each member state in which a migrant has worked have to make two calculations on their behalf: firstly, they determine the individual's statutory entitlements only for the years worked in this member state, using national legislation ('independent benefit'. ${ }^{6}$ ) Secondly, to avoid a situation in which mobile workers are penalised by rules favouring long-term members, such as a minimum period of insurance, national pension administrators also work out the pension entitlement of each mobile individual assuming that they spent their whole working career in this member state; on this basis, they apportion the individual's entitlement in relation to the actual time spent in this particular member state ('pro-rata benefit'). The individual will receive whichever of these two amounts is higher. Once benefits are in payment, they are exportable within the union, meaning a pensioner is free to move.

European regulation of non-statutory supplementary pension rights, that is, entitlements acquired under compulsory or voluntary occupational or personal pension schemes ${ }^{7}$ are much weaker, despite attempts by the EU since 2005 to strengthen protections. Most importantly, the compensation rules just described for state provision do not exist for non-state pensions, and therefore, the disadvantages created by short-term membership are not compensated in the same way (Oliver, 2009). Instead, laws are restricted to the following. First, workers who move to another country must be treated the same as native workers by national legislation for the time they spend in that country. This affects for example the treatment of vested pension rights (Directive 98/49/EC (29 June 1998) Art. 4). Secondly, providers of supplementary pension schemes must inform members who move to other member states about their rights (Art. 7). Finally, after the worker's retirement, providers must pay the pension to another member state, if required, net of taxes and transaction charges (Art. 5).

On the basis of this legislation, how confident can a mobile worker be they have the right to 
add all public and private entitlements from different EU countries? With regard to statutory provision, most of the literature suggests that mobile workers can be quite confident of adequate protection. Many studies assume that the legislation described previously prevents losses on account of mobility (Schmähl, 1993; Whiteford, 1996; Andrietti, 2001; Holzmann et al., 2005; Kalogeropoulou, 2006; Forteza, 2010). However, this claim has rarely been investigated empirically (see also Holzmann and Koettl, 2011:49), and when it has, problems have been identified (Wildasin, 1999; Fenge and von Weizsäcker, 2010). Where, for example, pension entitlement is based on an average annual amount using best years of earnings, such as under the French system, workers who move early in their career when their earnings are normally lower are likely to be disadvantaged compared with non-mobile workers. Problems can also be created by caps on pensions or minimum income top-ups (for details, see Fenge and von Weizsäcker, 2010).

The situation is even more problematic in the non-state occupational sphere. It is well known, for example, that defined benefit schemes tend to penalise early leavers (Schmähl, 1993; Whiteford, 1996; Andrietti, 2001; Kalogeropoulou, 2006), but these problems are further complicated when mobility is crossnational, because of the different regulatory frameworks, scheme designs and terminologies that exist between countries (Andrietti, 2001; Forteza, 2010). Defined contribution schemes are more portable than defined benefit schemes because after a vesting period, early leavers can normally withdraw the actuarially fair value of their pension funds (Andrietti, 2001). However, even with these schemes, Whiteford (1996: 253-254) has identified circumstances under which early leavers would be penalised. Moreover, although defined contribution pensions are more portable, they are also less generous than defined benefit schemes, thereby disadvantaging all workers (Bridgen and Meyer, 2005).

In summary, one important problem of pension right mobility, penalties for short-term membership, has been addressed by EU legislation for public pensions, but questions remain about the scope of this protection. Moreover, reliance on only one type of benefit is rare in Europe; many employees have additional non-state provision, the protection of which depends on the quality of national legislation. This varies between countries, creating unequal opportunities for workers from different countries. In addition, by focusing mainly on regulation, the literature has neglected two even more fundamental issues for pension mobility within the EU: the relative generosity of pension schemes and the potential impact of large national wealth variations on mobile workers. These topics were less salient before EU enlargement, which perhaps explains the neglect, but with increased migration they can no longer be ignored. We turn to them now.

\section{PRINCIPLES OF BEVERIDGEAN AND BISMARCKIAN PENSION REGIMES}

The comparative literature on pension regimes in Europe commonly divides EU countries into Beveridgean and Bismarckian pension regimes referring to public and non-state occupational systems (e.g. Bonoli, 2003; Ebbinghaus et al., 2011). A Beveridgean pension regime is characterised by a broad base, normally a public pension, which is universal and flat rate. Everyone or a very large share of the population is entitled to it, including those on part-time work, low wages and with family obligations, but benefits are fixed at the same level for all. This level can be at or above the poverty line to protect citizens from hardship. Poverty preventing universal pensions have long existed in most Beveridgean countries of Europe: Sweden, Norway, Denmark, Finland, the Netherlands and Switzerland, which base the public pension on citizenship. However, the level can also be below the poverty line, which was the case in the UK from 1945 to 2012 (Bridgen and Meyer, 2011).

Universal, flat-rate pensions are not sufficient for those on or above average incomes, no matter whether their level is at or below the poverty line. Higher earners expect to preserve their living standard in retirement, and therefore, strong occupational benefits developed in Beveridgean countries. These are income-related, and they increase the replacement rates of pensions to earnings in retirement. In most Beveridgean countries, occupational schemes were defined benefit schemes, but reforms since the mid-1990s have changed them to career average or defined contribution schemes. The benefits are still income-related, but much less predictable for the individual, because their final outcome is now 
tied to market dynamics and in many cases to the pace of demographic change (Ebbinghaus and Wi $\beta$, 2011).

In all Beveridgean countries except Britain, occupational pensions have been a mandatory part of the pension regime, and coverage was therefore high (Clasen et al., 2011: 292-3). In the UK, voluntarism prevailed until 2012, and therefore, this is the Beveridgean country with the lowest occupational coverage, never more than half of the working population in the private sector (Bridgen and Meyer, 2011).

Bismarckian pension regimes are characterised by earnings-related public contributions and benefits. Only those who have paid contributions receive a public pension, and if the career has been short or earnings low, for example because of part-time work, pensions will be low as well. Consequently, women are more vulnerable in a Bismarckian system than men, even though in most Bismarckian countries, care-related rights have been introduced into the public system. Because state pensions are generous for full-time workers, occupational benefits tend to be voluntary and are less developed in Bismarckian than in Beveridgean countries. Germany, Austria, France, Italy, Poland and Belgium are counted among the Bismarckian regimes (Bonoli, 2003; Clasen et al., 2011: 292).

The regime types are governed in different ways. The Beveridgean universal flat-rate pension is fully public, administered, regulated and delivered by the state; occupational pensions are normally mandatory, but they might be administered and delivered by employers or/and trade unions, or other non-state institutions. In the Bismarckian world, the full income-related pension is public, that is, in contrast to the Beveridgean system, there is only one tier governed by one set of rules. This difference also makes the calculation of mobile workers' statutory rights less complex in Bismarckian systems than in Beveridgean.

These systems emerged and evolved in national contexts; they were shaped by national political interests and reformed with citizens of nation states in mind. In contrast, our research focuses on citizens' pension entitlements accrued under different sets of national rules. By moving, a person might therefore leave a Bismarckian system and move to a Beveridgean one or the other way around. They might also move between two countries belonging to the same type of pension regime.

Copyright (c) 2013 John Wiley \& Sons, Ltd.
Considering these systems were not designed to enhance such mobility, how do their principles affect it?

\section{MIGRATION BETWEEN BISMARCKIAN AND BEVERIDGEAN REGIMES: GENEROSITY AND PRINCIPLES}

We have argued previously that mobility of social rights is not only a question of applying fairly the rules governing pensions in one country to another but that we also need to take into account the principles underlying national pension regimes, affecting their generosity, and the comparative wealth of countries. In fact, as the following will show, generosity and wealth difference have a significant impact on citizens' entitlements and might well be more important for mobility than the legislative protection of rights.

Table 3 compares generosity as determined by the main principles governing Beveridgean and Bismarckian regimes. To do this, we used the net replacement rates of public and mandatory private pensions of hypothetical workers after a full career under regulations valid in 2008 (OECD, 2011). With these replacement rates, we determined the pensions of workers in seven Bismarckian and six Beveridgean countries, assuming they spent their entire career under these pension regimes. We set these workers' last wage at 3000 ('the manager') and at 1500 Euro ('the assistant') monthly. ${ }^{8}$ In fact, of course, realaverage wage levels differ across the EU, but by using identical ones, we exclude the impact of differing national wealth from our calculation. This allows us to focus purely on the relative generosity of the different systems. Secondly, we wanted to assess how the average generosity of the two regimes might affect the manager and the assistant as mobile workers who migrate between the systems. Given that migrants often move when they are young, we assumed that the workers would spend 10 years in one regime and 35 in another.

Looking first at the generosity of the regimes for immobile workers, it emerges that higher earners are treated similarly in both types. The Bismarckian countries grant them an average replacement rate of $60.9 \%$, in comparison with $62 \%$ in the Beveridgean countries, leading to an almost equal pension in both systems. In contrast, lower earners are much better off in the Beveridgean countries, 
Table 3. Average generosity of Bismarckian and Beveridgean regimes in 2008 (Euro).

\begin{tabular}{|c|c|c|c|c|}
\hline & $\begin{array}{l}\text { Bismarck } \\
\text { manager }\end{array}$ & $\begin{array}{c}\text { Beveridge } \\
\text { manager }\end{array}$ & $\begin{array}{l}\text { Bismarck } \\
\text { assistant }\end{array}$ & $\begin{array}{c}\text { Beveridge } \\
\text { assistant }\end{array}$ \\
\hline Assumed gross monthly income at retirement & 3000 & 3000 & 1500 & 1500 \\
\hline Average net replacement rate, full career (\%) & 60.9 & 62.0 & 68.3 & 86.2 \\
\hline Standard deviation in group & 18.8 & 23.5 & 17.7 & 24.5 \\
\hline Lowest replacement rate in group & 33.3 & 26.8 & 33.2 & 62 \\
\hline Monthly pension after 45 years in regime of 2008 & 1827 & 1860 & 1024 & 1292 \\
\hline Monthly pension after 10 years in regime of 2008 & 406 & 413 & 228 & 287 \\
\hline Monthly pension after 35 years in regime of 2008 & 1421 & 1447 & 797 & 1005 \\
\hline $\begin{array}{l}\text { Beveridge monthly pension as \% of Bismarck, } \\
\text { any length }\end{array}$ & & 102 & & 126 \\
\hline \multicolumn{5}{|c|}{ Average monthly pension pension after $10+35$ years in two regimes } \\
\hline Movement & \multicolumn{2}{|c|}{ Bev to Bis } & \multicolumn{2}{|c|}{ Bis to Bev } \\
\hline Higher earner (2500 Euro) & \multicolumn{2}{|c|}{1834} & \multicolumn{2}{|c|}{1853} \\
\hline Lower earner (1500 Euro) & \multicolumn{2}{|c|}{1084} & \multicolumn{2}{|c|}{1233} \\
\hline $\begin{array}{l}\text { Higher earner - \% change in pension because of } \\
\text { movement }\end{array}$ & \multicolumn{2}{|c|}{99} & \multicolumn{2}{|c|}{101} \\
\hline $\begin{array}{l}\text { Lower earner - \% change in pension because of } \\
\text { movement }\end{array}$ & \multicolumn{2}{|c|}{84} & \multicolumn{2}{|c|}{120} \\
\hline
\end{tabular}

Source: OECD 2001: 115, 121, 127. Bismarckian countries: Austria, Belgium, France, Germany, Italy, Poland and Spain. Beveridgean countries: Denmark, Netherlands, Norway, Sweden, Switzerland and United Kingdom. Pensions are public and mandatory private benefits.

where they would receive $86.2 \%$ of last wages as a pension, about 24 percentage points more than in the Bismarckian group. Accordingly, their average pension in the Beveridgean is worth $20 \%$ more than in the Bismarckian countries. This illustrates the well-known higher degree of redistribution in the Beveridgean system, because of the universal flat-rate pension.

In relation to mobility therefore, the lower earner in Beveridgean countries would lose by moving to a Bismarckian country, and also if they moved from the more generous Beveridgean countries, namely the Netherlands or Denmark, to the least generous, the UK. By the same token, low earners in Bismarckian countries would gain by moving to a Beveridgean one. Although variation in the Beveridgean group is higher than in the Bismarckian (24.5 standard deviation Bev., 17.7 Bis.), even the lowest replacement rate for lower earners (62\% in the UK) is about double that of the lowest in the Bismarckian group (Poland). In contrast, for higher earners, the impact of mobility between Beveridgean and Bismarckian systems is less straightforward. Lowest replacement rates are very low for both groups (33.3 Bis., $26.8 \mathrm{Bev}$.) and outcomes vary substantially within each. Whether a higher earner lost out by moving would depend more therefore on the relative generosity of the particular national systems involved.

\section{MOVING FROM POOR TO RICH COUNTRIES: THE IMPACT OF NATIONAL WEALTH}

Freedom of movement is not just determined by different regime generosity but also by the differences in countries' wealth. For tables four, five and six, we have calculated pensions for immobile average-waged workers, using real national average earning figures for full-time workers in industry and services, all in Euro, and the OECD net replacement rates of public and mandatory private pensions of 2008 described previously. The tables allow us to compare the monthly national pensions and wages of these workers with one another. The tables show enormous wealth differences. For example, an immobile worker in Poland would receive a wage worth about $26 \%$ of an immobile worker in the Netherlands and a pension worth about 9\%, whereas if a Dutch immobile worker decided to retire in Poland, their pension would be more than 10 times higher than that of a pensioner who spent their career in Poland (Table 4). If we assume that these different wage and pension levels reflect different real costs of living, it is impossible for pensioners from the poorer countries, Romania and Poland to move to richer ones later in life.

This poses the question whether workers can move at all, unless they start their career in 
a richer country. The tables also show the entitlements of migrant workers who stay in their country of origin for 10 years, earning national average wages (in Euro) and who then spend 35 years of their career in their host country, earning the average there. Again, we use the OECD's replacement rates to calculate the monthly pension after 45 years and then work out the proportion for 10 and for 35 years. As we have shown previously, this is in line with EU legislation for public pensions. We have included the most common countries of origin over the last decade, Romania and Poland, and the most common host countries, Germany, the UK, Italy and Spain. We also wanted to cover two Beveridgean countries and therefore added the Netherlands to the sample. We assume that to speak of some degree of free movement for workers within the common market, they should be able to spend at least a quarter of their career in their home country and still be able to retire in their host country after a full working life. Is this the case?

Firstly, if we measure the outcome by comparing migrants' and non-migrants' pensions, the migrants from poorer countries have a pension worth $80-84 \%$ of that of an immobile worker in the host country, regardless of whether this is Spain, Italy, Germany, the UK or the Netherlands (Table 5). Their home pensions are so low that they count little overall. Migration therefore disadvantages these workers compared with immobile ones in the host country. By the same token, they would be much richer than their fellow countrymen if they returned to their country of origin to retire.

Secondly, we could also apply a relative poverty line of $60 \%$ average wages of the host country to see whether migrants on average national wages in each country they work in would be able to live a life without hardship in their host country upon retirement (Table 6). This appears to be possible for the Polish migrant to the Netherlands, who would be $33 \%$ above the Dutch poverty line; for the Romanian migrant to Spain, $14 \%$ above; the Romanian migrant to Italy would just miss this line. In contrast, the pensions of Polish migrants to the UK would be worth only just above half of this poverty line, and $76 \%$ if they went to Germany instead.

One could argue that the real test for whether migrants are truly mobile is whether it is more

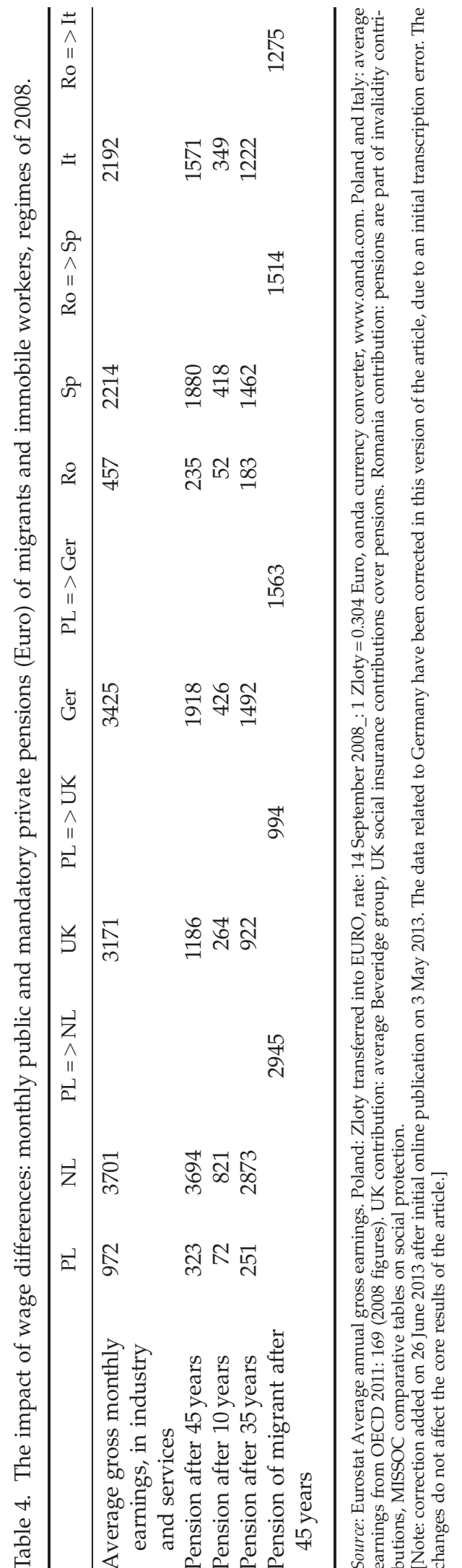

Popul. Space Place 19, 714-726 (2013) DOI: $10.1002 / \mathrm{psp}$ 
Table 5. Migrants' public and mandatory private pensions (10 years in home, 35 years in host county) as per cent of immobile workers and average wages (replacement rate).

\begin{tabular}{|c|c|c|c|c|c|c|c|c|c|c|}
\hline \multirow{2}{*}{ Migrant } & \multicolumn{2}{|c|}{ PL/NL of } & \multicolumn{2}{|c|}{$\mathrm{PL} / \mathrm{UK}$ of } & \multicolumn{2}{|c|}{ PL/Ger of } & \multicolumn{2}{|c|}{ Ro/Sp of } & \multicolumn{2}{|c|}{ Ro/Itof } \\
\hline & NL & PL & UK & PL & Ger & PL & $\mathrm{Sp}$ & Ro & It & Ro \\
\hline $\begin{array}{l}\text { Migrant's pension as \% of stationary } \\
\text { worker }\end{array}$ & 80 & 912 & 84 & 308 & 82 & 485 & 81 & 644 & 81 & 542 \\
\hline $\begin{array}{l}\text { Migrant's pension as \% of average } \\
\text { wage }\end{array}$ & 80 & 303 & 31 & 102 & 46 & 161 & 68 & 331 & 58 & 279 \\
\hline
\end{tabular}

Source: as in Table 4.

[Note: correction added on 26 June 2013 after initial online publication on 3 May 2013. The data related to Germany have been corrected in this version of the article, due to an initial transcription error. The changes do not affect the core results of the article.]

Table 6. Public and mandatory private pensions of immobile and migrant workers on average and $50 \%$ average wages in relation to poverty line $(60 \%$ average wages).

\begin{tabular}{lcccccrr}
\hline & $\mathrm{PL}$ & $\mathrm{PL}=>\mathrm{NL}$ & $\mathrm{PL}=>\mathrm{UK}$ & $\mathrm{PL}=>$ Ger & Ro & Ro $=>\mathrm{Sp}$ & Ro $=>\mathrm{It}$ \\
\hline $\begin{array}{l}\text { Average-waged worker's pension } \\
\text { Half average-waged worker's }\end{array}$ & 55 & 133 & 52 & 76 & 86 & 114 & 97 \\
$\quad \begin{array}{l}\text { pension } \\
\text { P }\end{array}$ & & 69 & 42 & 37 & 51 & 55 & 49 \\
\hline
\end{tabular}

Source: as in Table 4. Migrants: 10 years in home and 35 years in host country. Migrants' pensions calculated in relation to host country's poverty line.

difficult for them to receive a pension above the poverty line in their host country than in their country of origin. Therefore, thirdly, we calculated whether migrants are better protected against poverty when they retire abroad, after 10 years in their country of origin and 35 years in their host country, than workers who stayed in the country of origin (Table 6). Considering the large wage differences, one would perhaps have expected that the country of origin would be more favourable in this regard. However, this is not true. Surprisingly, all migrants on average wages are at least as well protected against poverty in their host country as they would have been if they had remained immobile, with many achieving a pension significantly closer to the poverty line than they would have if they had stayed in their home country: this is true for Polish migrants to the Netherlands and to Germany, but also for Romanian migrants on average wages to Spain and Italy. The one exception is the Pole going to the UK, whose pension in relation to the poverty line would be 3 percentage points higher in Poland (55\%) than in Britain. This is because the British state pension as a share of the average wage was among the lowest in the sample, 37.4\% in 2008 (authors' calculations, table not shown, sources as Table 4); its proportional reduction by 10 years for the migrant

Copyright (c) 2013 John Wiley \& Sons, Ltd. worker from Poland depressed the overall level further, whereas the value of the entitlements for contributions in Poland over 10 years was too low to compensate for this loss. The Polish state and compulsory pension was even lower in relation to average wages (33\%), but it did not have to be reduced for the immobile Polish worker, and therefore, the pension is slightly closer to the poverty line than for the Polish migrant retiring in Britain. However, the difference between the two relative pensions is small, and both workers would retire to poverty without additional voluntary provision; on this basis, we conclude that for the Pole, remaining immobile is as good or bad as migrating. ${ }^{9}$

Table six also shows the results for workers on low wages, taking into account their higher replacement rates in some countries. In this case, all Polish migrants do better in their host country, including the migrant to the UK, who benefits from the compensatory measures in the British system for those on low income. The Romanians do better in Spain and a little less well only in Italy.

Our findings suggest that moving from poor to rich countries does not disadvantage migrants with a full employment career if they spend at least $80 \%$ of this career in the richer ones. Indeed, many achieve pensions higher than possible in 
their countries of origin. They are still disadvantaged in comparison with the immobile nationals of their host country, but their chance to escape poverty is better or as good in the host country as it would have been at home. Of course, this comparative advantage would gradually reduce if a potential migrant stays longer in their poorer host country before moving, because firstly, replacement rates and principles of these systems are less generous. Replacement rates in Romania $(51.5 \%)^{10}$ and Poland $(33.2 \%)$ are lower than anywhere else in the Bismarckian (64\% average) and Beveridgean group (67.5\% average), with the exception of the UK (37.4\%). Secondly, significant differences in wage levels will not allow citizens from the east to move and retire in the richer west, unless they migrate early in their career.

\section{THE BENEFITS OF MIGRATION}

The aim of this paper was to explore how mobile pensions are within the EU and whether workers will be penalised for their mobility when they retire. We have shown that EU legislation protects workers moving between public pension systems to some extent and that occupational pension rights are regulated only at national level, exposing workers to the distortions that affect early leavers of schemes. For a long time, this deficiency mattered less in practice, because relatively few EU citizens moved between countries. However, the enlargement of the EU has encouraged large numbers of migrants to move from east to west, changing this situation.

Previous academic work on the portability of social rights has examined the mobility of public pensions (for example Schmähl, 1993; Whiteford, 1996; Holzmann et al., 2005; Kalogeropoulou, 2006) and how mobility affects occupational pension outcomes (for example Andrietti, 2001; Forteza, 2010); but it has been patchy from a comparative perspective, covering only certain countries and certain scheme types; in addition, public and occupational rights have been analysed independently of each other, leading to incomplete assessments of their intertwined nature. Moreover, consideration has focused on the impact of legislation on the preservation of pension rights, not on the impact of movement between different types of pension system and between nations of widely differing levels of wealth. Despite these limitations, existing empirical studies largely agree that mobile workers are disadvantaged in comparison with

Copyright (c) 2013 John Wiley \& Sons, Ltd. immobile ones, even though EU legislation has removed some disadvantages for public pensions.

This paper differs from the previous literature in that it has sought to adopt a more comprehensive, integrated assessment of pension mobility on the basis of the argument that analysis of pension right mobility must recognise that different system principles and generosity as well as national wealth differences are significant for the relative position of mobile workers and that they might in fact matter more than portability legislation. On the basis of this approach, our answer to the question of disadvantage through mobility is more nuanced than that in the literature. On the one hand, we agree that the rules governing public and occupational systems favour stability and sanction movement. Moreover, this view is partially reinforced by our analysis of movement between varying types of pension systems, which shows that this can be a problem for some workers. Thus, when keeping average wage levels between countries constant, lowincome workers who move from a Beveridgean system to a Bismarckian are vulnerable to a pension loss. This is because of the greater level of redistribution in the former type. For this group of workers, movement in this way is likely to incur a cost.

However, our findings also conflict with the consensus view in the literature: when pension system type and comparative wealth are included in the analysis, some workers are not disadvantaged on retirement by mobility. Importantly, the group for which this is most true - workers moving from the poorer east to the richer west, from Bismarckian systems of low generosity to Beveridgean and more generous Bismarckian systems - make up the majority of intra-EU migrants today. Our research shows that these workers are more likely to gain than to lose if they spend at least $80 \%$ of their career in a western host country, because of more generous regime principles, expressed by higher replacement rates. In addition, the fact that the western economies are richer and pay much higher wages has a big impact. Even incomplete participation in the wealth of the more mature economies and welfare states of the west leads to better protection against poverty than staying in the less developed east.

Despite our insistence on a broader concept when evaluating mobility, we still think that better protection of occupational pension rights for mobile workers should be a policy priority for the EU Council. In most developed economies, 
non-state pensions are growing, and policy makers want citizens to rely on them more. This shift should be accompanied by legislative protection mirroring that of public benefits. At present, reliance is placed on national protections about which very little is known: information on how EU member states deal with occupational rights of mobile workers, that is, of early leavers or late joiners of schemes is patchy and no inclusive overview exists. A comparative database on national non-state pension regulation across the EU would have to be established before broader assessments of these protections could be made; but we are a long way away from such a base, not least, because in many countries, companies are not required to publish details of their voluntary pension packages. Even though this might not matter as much for many of today's migrants, the stark wealth differences between countries might erode over the next two decades, making the improved protection of occupational rights more relevant for all. Besides, there are employees moving between the richer nations today, and even though they are in a minority, there is no reason why they should be disadvantaged in comparison with immobile workers.

\section{NOTES}

(1) The Treaty establishing the European Economic Community in 1957 focused on the establishment of a common market and thus on the rights of citizens as workers. This did not normally include political rights and social rights only insofar as they were directly related to employment. This focus on the market has remained, even though the legislation needed for it has broadened over time.

(2) To assess the full political and administrative pressures EU member states face through immigration, we also included migration data from developed industrialised democracies outside the EU. Thus, we added to all EU 27 countries the remaining OECD countries that are not EU member states. We refer to the result as EU + OECD countries. We excluded less developed non-EU countries because these migrants are less likely to acquire pension rights.

(3) We use data on foreign nationality when using Eurostat and OECD figures on the size of the EU foreign population as these data are more comprehensive than data on foreign-born.

(4) We attribute this to a large number of Turkish citizens because second generation Turks born in
Germany prior to 2000 were given Turkish citizenship (Alba, 2005).

(5) A minor amendment was made in 2010 (Regulation $883 / 2004)$ but the regulation's fundamental principles remain intact (Verschueren, 2009).

(6) Referred to as 'theoretical amount' in Regulation $1408 / 71$, changed to 'independent benefit' in Regulation $883 / 2004$.

(7) The EU allows member states to voluntarily apply the EU legislation in place for state pensions (i.e. Reg. 883/2004) to their compulsory non-state systems, but to our knowledge, only France has yet asked for this legislation to be extended in this way (OJ C135/17, 5.5.2011).

(8) These labels are only meant to illustrate easily wage difference, they are not based on real earning figures.

(9) In addition, the British public pension has been reformed since 2008, leading to an increase in the basic state pension; thus, from 2011, the Polish full-time worker would be better off in the UK, too (Bridgen and Meyer, 2011).

(10) Data from Romanian Labour Ministry, (www. mmuncii.ro)

(11) We include under the term European Union (EU) developments in the European Communities (EC), the predecessor of the EU (1958-1992).

\section{REFERENCES}

Ahonen EQ, Porthé V, Vázquez ML, García AM, LópezJacob MJ, Ruiz-Frutos C, Ronda-Pérez E, Benach J, Benavides FG. 2009. A qualitative study about immigrant workers' perceptions of their working conditions in Spain. Journal of Epidemiology and Community Health 63: 936-942. DOI:10.1136/jech.2008.077016

Alba R. 2005. Bright vs. blurred boundaries: secondgeneration assimilation and exclusion in France, Germany, and the United States. Ethnic and Racial Studies 28: 20-49. DOI:10.1080/0141987042000280003

Alexandru M. 2007. Migration and social mobility. a new perspective on status inconsistency. The Romanian Journal of European Studies 5-6.

Andrietti V. 2001. Portability of supplementary pension rights in the European Union. International Social Security Review 54: 59-83.

Black R, Engbersen G, Okolski M, Pantiru C. (eds). 2010. A continent moving west?: EU enlargement and labour migration from Central and Eastern Europe. Amsterdam University Press; Manchester University Press distributor: Amsterdam: Manchester.

Bonoli G. 2003. Two worlds of pension reform in Western Europe. Comparative politics 35(4): 399-416.

Bridgen P, Meyer T. 2005. When do benevolent capitalists change their mind? Explaining the 
retrenchment of final salary pensions in Britain. Social Policy and Administration 39(7): 764-785. DOI:10.1111/j.1467-9515.2005.00468.x

Bridgen P, Meyer T. 2011. Great Britain: exhausted voluntarism - the evolution of the British liberal pension regime. In Governance of Supplementary Pensions in Europe: The Varying Scope for Participatory and Social Rights, Ebbinghaus B, Gronwald M, Wiss T (eds). Oxford University Press: Oxford; 265-291.

Clasen J, Mau S, Meyer T, Seeleib-Kaiser M. 2011. Conclusion: parallel paths, great similarities, remaining differences. In Converging Worlds of Welfare? British and German Social Policy in the 21st Century, Clasen J (ed.). Oxford University Press: Oxford; 180-217.

Council Directive 98/49/EC of 29 June 1998 on safeguarding the supplementary pension rights of employed and self-employed persons moving within the Community. Official Journal of the European Communities L 209/46 25 July 1998.

Council Regulation (EC) No 1408/71 of 14 June 1971 on the Application of Social Security Schemes to Employed Persons, to Self-Employed Persons and to Members of their Families Moving Within The Community. Official Journal of the European Communities L 149, 5 July 1971 p.2.

Council Regulation (EC) No 883/2004 of the European Parliament and of the Council of 29 April 2004 on the Coordination of Social Security Systems. Official Journal of the European Union L 200, 7 June 2004.

Ebbinghaus B, Wi $\beta$ T. 2011. The Governance and Regulation of Private Pensions in Europe. In Varieties of Pension Governance: The Privatization of Pensions in Europe, Ebbinghaus B (ed.). Oxford University Press: Oxford; 351-383.

Ebbinghaus B, Gronwald M, Wi $\beta$ T. (eds). 2011. Governance of Supplementary Pensions in Europe: The Varying Scope for Participatory and Social Rights. Oxford University Press: Oxford.

European Commission. 2011. Notification by the French Government to the European Parliament and to the Council. Official Journal of the European Q9 Union, C 135/17, 5.5.2011, p.1.

Fenge R, von Weizsäcker J. 2010. Public pension systems and distortions of intra-EU mobility: the Lodge Test. Journal of Pension Economics E Finance 9: 263-275.

Forteza A. 2010. The portability of pension rights: general principles and the Caribbean case. Development Policy Review 28: 237-255. DOI:10.1111/ j.1467-7679.2010.00483.x

Holzmann R, Koettl J. 2011. Portability of pension, health, and other social benefits: facts, concepts, issues. Social Protection Discussion Papers 62725. Available at: http://ideas.repec.org/p/wbk/hdnspu/62725. html [Accessed 6 December 2011].

Holzmann R, Koettl J, Chernetsky T. 2005. Portability regimes of pension and health care benefits for international migrants: an analysis of issues and good practices. Paper prepared for the Global Commission on International Migration, 23 May, Geneva, GCIM.

Kalogeropoulou K. 2006. Improving the portability of supplementary pension rights. Journal of Social Welfare and Family Law 28: 95-104. DOI:10.1080/ 09649060600762472

MISSOC (Mutual Information System on Social Protection) comparative tables on social protection. Available at: http://ec.europa.eu/employment_social/missoc/ $\mathrm{db} /$ public/compareTables.do?lang=en [Accessed 20th May 2012].

OECD. 2011. Pensions at a Glance 2011. Retirement income systems in OECD and G20 countries. OECD: Paris.

Oliver E. 2009. From portability to acquisition and preservation: the challenge of legislating in the area of supplementary pensions. Journal of Social Welfare and Family Law 31: 173-183. DOI:10.1080/ 09649060903043547

Puhani PA. 2001. Labour mobility: an adjustment mechanism in Euroland? Empirical evidence for Western Germany, France and Italy. German Economic Review 2: 127-140. DOI:10.1111/1468-0475.00031

Schmähl W. 1993. Harmonization of pension schemes in Europe? A controversial issue in light of economics. In Age, work and social security, Rein M, Atkinson AB (eds). Macmillan: Basingstoke.

Straubhaar T. 1988. International labour migration within a common market: some aspects of EC experience. Journal of Common Market Studies 27: 45-62. DOI:10.1111/j.1468-5965.1988.tb00329.x

Treaty establishing the european economic community (Rome, 25 March 1957, T.S. 1 (1973): Cmnd 5179) (EC Treaty).

Tsoukalis T. 1997. The New European Economy revisited. Oxford University Press: Oxford.

Verschueren H. 2009. Regulation 883/2004 and invalidity and old-age pensions. European Journal of Social Security 11(1-2): 143-162.

Whiteford EA. 1996. Adapting to change: occupational pension schemes, women and migrant workers: an examination of the extent to which occupational pension schemes in the UK, the Netherlands and Germany enable women and migrant workers to accrue adequate pensions. Kluwer Law International; The Hague: London.

Wildasin DE. 1999. Public pensions in the EU: migration incentives and impacts. Available at: http:// davidwildasin.us/pub/Wildasin-Public-PensionsMigration-EU.pdf [Accessed 18 March 2012]. 